\title{
THE ACCESSIBILITY OF BUILDINGS AND HOUSES FOR DISABLED PERSONS: THE LAW AND PRACTICE IN MALAYSIA*
}

\author{
Azlinor Sufian*
}

\begin{abstract}
Malaysia is one of the signatories to the proclamations of Asia \& Pacific Decade of Disabled Persons (1993-2002), yet Malaysia is still lacking of comprehensive laws as regards to rights of persons with disabilities. The only law available is the Uniform Building (Amendment) By Laws, 1991(UBBL Amendment 1991) that provides for building requirements for disabled persons. This by law may be regarded as an initial step taken by Malaysia to ensure a disabled person's right to full participation in social development. Despite the existence of this by law, most buildings in Malaysia do not have proper facilities or provide easy access for persons with disabilities. Similarly as far as housing is concerned there is no statutory requirement stipulating that housing (in particular public housing) should be designed to accommodate
\end{abstract}

A revised version of a paper presented at the World International Conference on Accelerating Excellence in the Built Environment, University of Wolverhampton, United Kingdom on $2^{\text {nd }}-4^{\text {th }}$ October 2006. Assistant Professor, Ahmad Ibrahim Kulliyyah of Laws, International Islamic University Malaysia. 
the needs of persons with disabilities. It is the aim of this article to look into some legal provisions related to barrier free buildings including housing in Malaysia.

\section{INTRODUCTION}

A serious commitment by the Malaysian government towards providing rehabilitation programmes for disabled persons began in the early $20^{\text {th }}$ century which involved 4 ministries; i.e. the Ministry of Social Welfare (now renamed as Ministry of National Unity and Social Development), the Ministry of Education, the Ministry of Health and the Ministry of Labour and Manpower (now renamed as the Ministry of Human Resources). ${ }^{1}$ Since then many programmes have been developed for persons with disabilities which aims to improve the quality of their lives. ${ }^{2}$ In this article the issues related to persons with disabilities will be discussed from the perspective of the built environment in which reference shall be made to the Building (Federal Territory of Kuala Lumpur)(Amendment) By-Laws 1992 that provides for building requirements for disabled persons and brief discussions on the practices in Singapore.

It will also look at the viability of improvements in the existing system.

$1 \quad$ For further reading on background and national policies for disabled persons refer to Md. Rashid, Country Paper: Malaysia, a paper presented at Expert Group Meeting and Seminar on an International Convention to Protect and Promote the Rights and Dignity of Persons with Disabilities, Bangkok, Thailand, 2-4 $4^{\text {th }}$ June 2003.

2 See Denison Jayasoria, Disabled People, Citizen and Social Work: The Malaysian Experience, ASEAN Academic Press, London, 2000 for discussion on programmes related to disabled people which include direct and indirect participation of the government as well as the nongovernmental organization. 


\section{DEFINITION OF DISABLED PERSONS}

In Malaysia matters concerning disabled persons specifically fall under the jurisdiction of the Department of Social Welfare of the Ministry of National Unity and Social Development. The department adopts the definition of a "disabled person" as given by the United Nations and World Health Organisation (WHO). The definition reads as follows:

"any person unable to ensure by himself or herself, wholly or partly, the necessities of a normal individual and/or social life as the result of a deficiency, either congenital or not, in his or her physical or mental capabilities which may have happened before or after childbirth."3

The above definition has been used as a guideline by the government to formulate the law, policy and programmes to aid persons with disabilities in Malaysia. The definition is based on the medical model of disability and apparently will include disabilities due to age. ${ }^{4}$ In the context of built environment, the Malaysian building by-laws has embraced

http://www.apcdproject.org/Countryprofile/malaysia.html. It has been commented that this definition is not comprehensive enough since it merely based on medical disability and does not take into account social, environmental and economic factors affecting disability. See this discussion in Majid Turmusani, Disabled People and Economic Needs in the Developing World: Political Perspective From Sudan, Ashgate Publishing Ltd, England, 2003, pp. 15-16.

There are a few specific researches on the need of consumers and building design for the elderly in Malaysia. See for instance Asiah Abdul Rahim, Keperluan Pengguna dan Reka Bentuk Bangunan untuk Warga Tua di Malaysia, Research Centre, International Islamic University Malaysia, Kuala Lumpur, 2006 and Sharifah Norazizan Syed Abd Rashid and Norbaya Ahmad, Planning for Ageing In-Placetowards an Ergonomically Designed Home Environment for Older Malaysian, a paper presented at the 8th International Conference of the Asian Planning Schools Association (APSA). School of Housing, Building and Planning, University of Science Malaysia. Grand Plaza Park Royal, Batu Ferringhi, Penang, Malaysia. 11 ${ }^{\text {th }}-14^{\text {th }}$ September 2005. 
the meaning of a disabled person from the medical perspective where it states that:-

a disabled person is a person with a physical, hearing or sight impairment which affects his/her mobility or his/her use of buildings (in which the types of buildings are specifically laid down in the by-laws). ${ }^{5}$

A clear understanding on the types of disabilities would help designers suggest the form of barrier free buildings and housing to cater to several categories of disabled persons. For instance access concerns for persons with orthopaedic disabilities are in relation to physical and structural barriers. In the case of persons with sensory and/or intellectual disabilities, the concern is related to barriers involving communication and information services. For instance, persons with orthopaedic disabilities require audio-visual signs and tactile guide-blocks. ${ }^{6}$ Therefore, it is felt that in designing barrier free buildings (public and commercial) and housing, apart from relying on the creativity and sensitivity of the architect, the opinion and experience of disabled persons (resource persons) are not less important.

\section{STATISTICS ON PERSONS WITH DISABILITIES}

In Malaysia the registration of disabled persons is done voluntarily. It means that there is no compulsion on parents or the head of families to register the disabled persons in his family. However, when the government started to promote several facilities to the disabled, it has indirectly encouraged parents/heads of a family to register their disabled family members with the Department of Social Welfare. ${ }^{7}$ The number of registered disabled persons has increased from year to year as shown in Table 1 below:

$5 \quad$ By-law 2 Building (Federal Territory of Kuala Lumpur) (Amendment) By-Laws 1992. This definition is also similar with Part M (Access and Facilities for Disabled People) Building Regulations (Amendment), 1998 of the United Kingdom.

6 http://www.unescap.org/esid/psis/disability/decade/publications/ zl5008cs/zl500802.htm 


\section{Table 1}

\section{Registration of Disabled Person (2001-2005)}

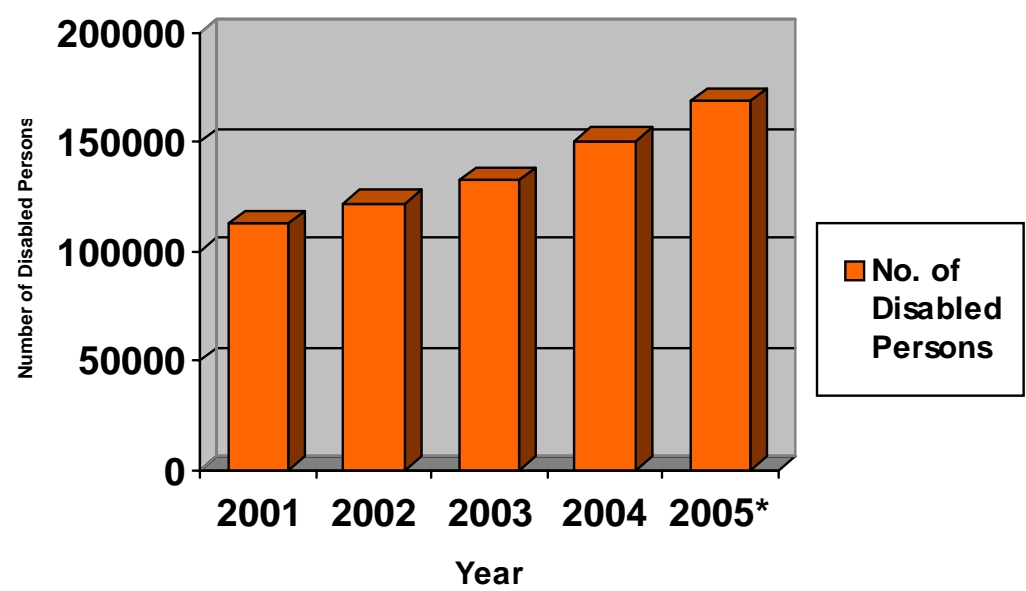

Source: Department of Social Welfare, Malaysia.

* The statistic does not include the state of Pahang, Perak, Kelantan and Perlis.

For instance, the disabled persons will be given financial aid of between RM80.00 to RM350.00 per month, a disabled worker will be given an allowance of RM200.00 per month if his monthly income does not exceed RM500.00, a monthly allowance of RM25.00 per person is given to disabled students in primary and secondary schools, a $20 \%$ discount to buy low-cost house, 50\% discount on local airfare and train fare, no road tax for locally made vehicles owned by a disabled person and for civil servants with disabled children the government will allow them to work on flexi-hours to facilitate them in caring for their children. 


\begin{tabular}{|c|c|}
\hline Year & $\begin{array}{l}\text { No. of Disabled } \\
\text { Persons }\end{array}$ \\
\hline 2001 & 112,624 \\
\hline 2002 & 122,089 \\
\hline 2003 & 132,157 \\
\hline 2004 & 150,617 \\
\hline $2005 *$ & 168,655 \\
\hline
\end{tabular}

Disabled persons may be classified into several types of disabilities as shown in Table 2 and the majority of them are physically and mentally impaired. On the other hand Table 3 shows that in the year of 2001, 2002, 2003 and 2004 the five states in Malaysia i.e Perak, Kuala Lumpur, Selangor, Johore and Kelantan were the first five states, which recorded the highest number of registration of disabled persons. Throughout this period of 2001 to 2004, the highest number of disabled persons was recorded among Malays as compared to other ethnic groups in Malaysia as reflected in Table 4.

Table 2

\section{$\underline{\text { Registration of Disabled Person According to Types of Disablities }}$}

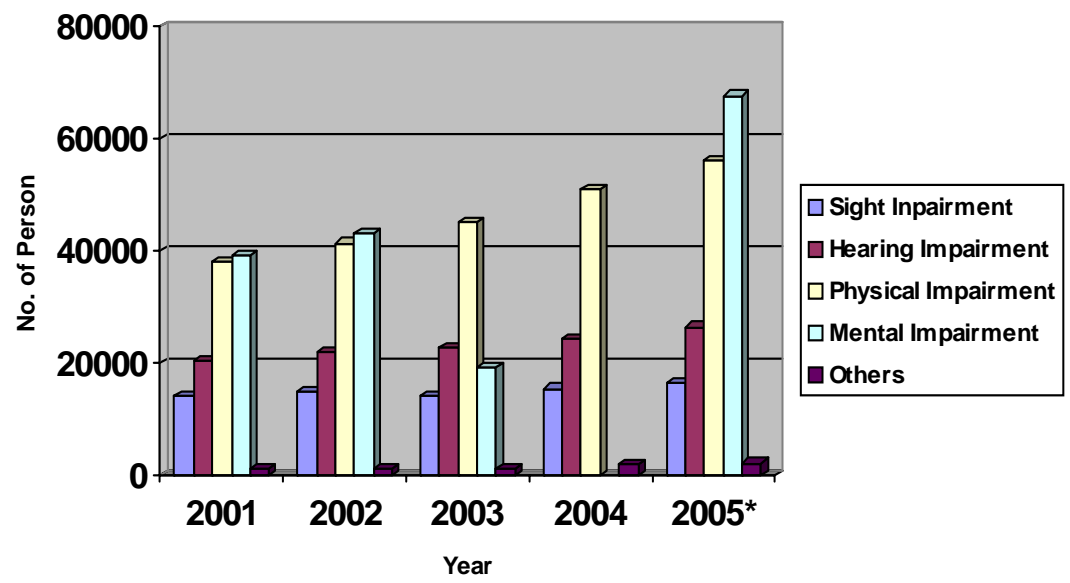

Source: Department of Social Welfare, Malaysia.

* The statistic does not include the state of Pahang, Perak, Kelantan and Perlis. 


\begin{tabular}{|c|c|c|}
\hline Year & Type of Disabilities & $\begin{array}{l}\text { No. of Registered } \\
\text { Disabled Persons }\end{array}$ \\
\hline \multirow[t]{5}{*}{2001} & Sight Impairment & 13,968 \\
\hline & Hearing Impairment & 20,443 \\
\hline & Physical Impairment & 38,051 \\
\hline & Mental Impairment & 39,150 \\
\hline & Others & 1,012 \\
\hline \multirow[t]{5}{*}{2002} & Sight Impairment & 14,738 \\
\hline & Hearing Impairment & 21,981 \\
\hline & Physical Impairment & 41,311 \\
\hline & Mental Impairment & 43,042 \\
\hline & Others & 1,017 \\
\hline \multirow[t]{5}{*}{2003} & Sight Impairment & 14,142 \\
\hline & Hearing Impairment & 22,662 \\
\hline & Physical Impairment & 45,164 \\
\hline & Mental Impairment & 19,109 \\
\hline & Others & 1,080 \\
\hline \multirow[t]{5}{*}{2004} & Sight Impairment & 15,364 \\
\hline & Hearing Impairment & 24,712 \\
\hline & Physical Impairment & 51,090 \\
\hline & Mental Impairment & \\
\hline & Others & 1,934 \\
\hline \multirow{5}{*}{$2005 *$} & Sight Impairment & 16,311 \\
\hline & Hearing Impairment & 26,525 \\
\hline & Physical Impairment & 56,103 \\
\hline & Mental Impairment & 67,643 \\
\hline & Others & 2,073 \\
\hline
\end{tabular}




\section{Table 3}

\section{Registration of Disabled Person According to States}

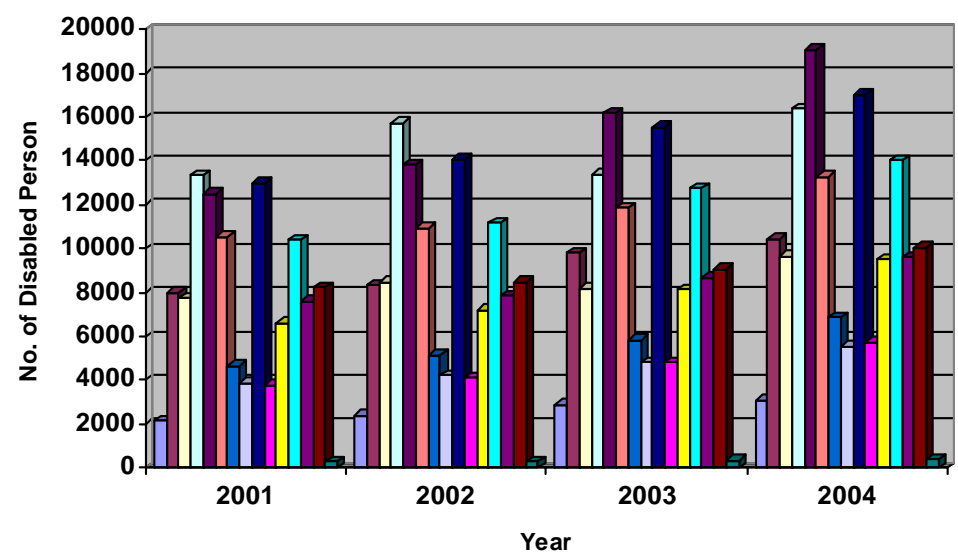

Statistics Profile 2004: Department of Social and Welfare, Malaysia. (2001-2004)

\begin{tabular}{|l|l|l|l|l|}
\hline \multicolumn{1}{|c|}{ States } & \multicolumn{1}{c|}{$\mathbf{2 0 0 1}$} & \multicolumn{1}{c|}{$\mathbf{2 0 0 2}$} & \multicolumn{1}{c|}{$\mathbf{2 0 0 3}$} & \multicolumn{1}{c|}{$\mathbf{2 0 0 4}$} \\
\hline Perlis & 2,152 & 2,382 & 2,866 & 3,065 \\
\hline Kedah & 7,973 & 8,305 & 9,823 & 10,459 \\
\hline Penang & 7,750 & 8,476 & 8,165 & 9,646 \\
\hline Perak & 13,363 & 15,755 & 13,389 & 16,401 \\
\hline Selangor & 12,516 & 13,837 & 16,174 & 19,073 \\
\hline Luala Lumpur & 10,523 & 10,921 & 11,857 & 13,295 \\
\hline Negeri Sembilan & 4,632 & 5,138 & 5,826 & 6,834 \\
\hline Malacca & 3,865 & 4,197 & 4,775 & 5,530 \\
\hline Johore & 12,988 & 14,089 & 15,543 & 17,040 \\
\hline Pahang & 3,762 & 4,088 & 4,791 & 5,715 \\
\hline Treengganu & 6,616 & 7,208 & 8,123 & 9,486 \\
\hline Kelantan & 10,383 & 11,149 & 12,763 & 14,017 \\
\hline Sarawak & 7,595 & 7,833 & 8,670 & 9,634 \\
\hline Sabah & 8,258 & 8,462 & 9,067 & 10,049 \\
\hline Labuan & 248 & 250 & 320 & 373 \\
\hline Total & 112,624 & 122,089 & 132,655 & 150,617 \\
\hline
\end{tabular}




\section{Table 4}

\section{Registration of Disabled Person According to Ethnicity}

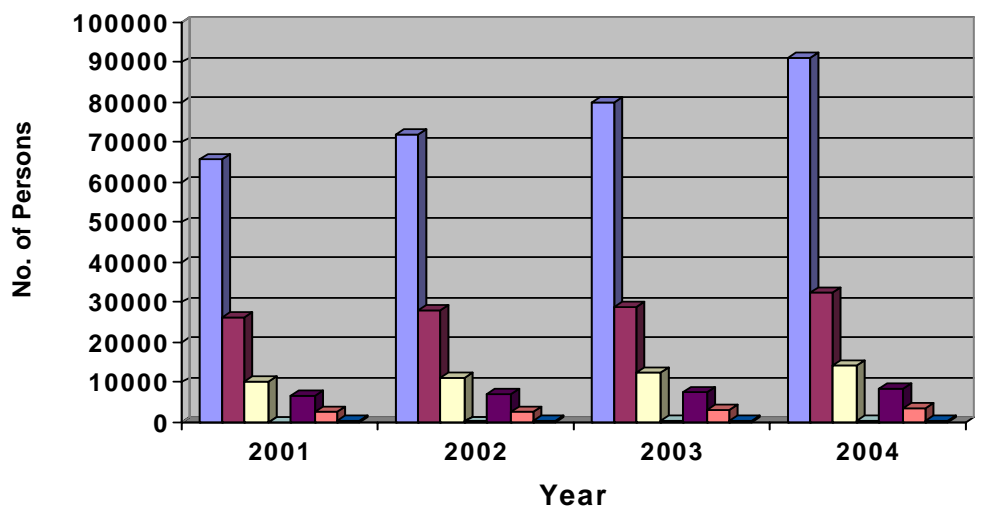

\begin{tabular}{|ll|}
\hline Malay in Penisular Malaysia & $\square$ Chinese \\
$\begin{array}{l}\text { Native in Sabah } \\
\text { Others }\end{array}$ & $\square$ Native in Sarawak \\
\hline
\end{tabular}

\begin{tabular}{|c|c|c|c|c|}
\hline Ethnic Group & 2001 & 2002 & 2003 & 2004 \\
\hline Malay & 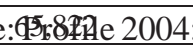 & Deppaqment o & 80,837 and & 19arı,6Ralaysia \\
\hline Chinese & 26,228 & 28,088 & 28,956 & 32,408 \\
\hline Indian & 10,255 & 11,309 & 12,396 & 14,246 \\
\hline $\begin{array}{l}\text { Native in } \\
\text { Peninsular } \\
\text { Malaysia }\end{array}$ & 211 & 242 & 246 & 283 \\
\hline Native in Sabah & 6,835 & 6,993 & 7,515 & 8,266 \\
\hline $\begin{array}{l}\text { Native in } \\
\text { Sarawak }\end{array}$ & 2,826 & 2,825 & 3,226 & 3,617 \\
\hline Others & 447 & 484 & 479 & 635 \\
\hline & 112,624 & 122,089 & 132,655 & 150,617 \\
\hline
\end{tabular}

Source: Profile 2004: Department of Social and Welfare, Malaysia. (2001-2004) 


\section{LAWS AND LEGISLATION ON DISABLED PERSONS AND BARRIERS IN THE ENVIRONMENT}

There is no comprehensive law regulating the rights of disabled persons in Malaysia. In other countries for instance such as the United Kingdom, ${ }^{8}$ Fiji, ${ }^{9}$ India,,${ }^{10}$ Japan, ${ }^{11}$ Australia ${ }^{12}$ and Ceylon, ${ }^{13}$ the rights of the disabled are clearly spelt out in a specific statute. Malaysia is still on course towards promulgation of specific legislation where the draft of the Disabled Persons, Act has been submitted to the authorities and still awaiting for further actions. ${ }^{14}$ In absence of any explicit statutory protection for disabled persons in Malaysia, recourse may be made to any available means in which the closest statutory protection would be via articles $5^{15}$ and $8^{16}$ of the Malaysian Federal Constitution 1957. These 2 constitutional articles are among the fundamental rights that are described as fundamental liberties in the constitution. These fundamental liberties can be said to be a bill of rights as the provisions regarding

\footnotetext{
$8 \quad$ Disability Discrimination Act 1995.

$9 \quad$ National Council for Disabled Persons Act 1994.

10 Persons With Disabilities (Equal Opportunities, Protection of Rights and Full Participation) Act 1995.

11 Disabled Persons Fundamental Law.

$12 \quad$ Anti Discrimination Act 1992.

13 Rights of Persons with Disabilities Act, 1996.

14 The duty to draft the Disabled Persons Act is entrusted to the Technical Working Group established under the Advisory and Consultative Council for People with Disabilities. The Council is chaired by the Minister of the Ministry of National Unity and Social Development. In 2002 the draft has been submitted to the Council for endorsement. The draft of the act will be discussed further with relevant agencies and other interested groups before presenting it in parliament. The Technical Working Group is also entrusted to review existing legislation to ensure conformity with the Draft of the Disabled Persons Act which focuses on the rights of the disabled to equality before the law, to eliminate discrimination against the disabled and to promote recognition and acceptance of the disabled within the community. Article 5 provides that "No person shall be deprived of his life and personal liberties save in accordance with the law."

16 "Every person is equal before the law unless conditions expressly authorised by the Constitution."
} 
fundamental liberties are also about human rights which has been accepted by the international community. ${ }^{17}$ This article will not replicate discussions in previous writings which already pointed out the current judicial trend to embrace a liberal interpretation of the phrase "right to life" in article $5^{18}$ inter alia to include the right to continue in public service subject to removal for good cause by resort to fair procedure, ${ }^{19}$ right to livelihood, ${ }^{20}$ right to be engaged in lawful and gainful employment ${ }^{21}$ and reputation. ${ }^{22}$ The expansion of meaning of the phrase "right to life" in those contexts may be employed as a basis to include the right of disabled persons to be provided with proper access to building and housing suited with their physical impediments. On the other hand, the provision of article 8 on

17 In Malaysia there is a Human Rights Act, 1999. This act however does not create any new rights other than those already accepted as fundamental liberties under the Federal Constitution. See Tomislav Simeeek, Fundamental Human Rights or the "Right to Housing"?, in International Conference on Housing in an Expanding Europe: Theory, Policy, Participation and Implementation, Ljubljana, Slovenia 2-5 July 2006 who has commented that lately a new breed of "rights" has arisen. These "rights" include a claim to everything from a "decent" level of clothing, food, housing, medical care, old age pension, education, work or unemployment benefits and good living standard. He further asserts that the rights of an individual are not only confined to be left alone, free to build, buy or rent whatever shelter he can afford, but it is now extended to right to housing which implies an obligation on the part of other people to provide such housing. This claim in other words, is for a so-called positive right, not the fundamental negative right of classical origin.

18 See for instance Abdul Haseeb Ansari, "Right to a Healthful Environment as a means to ensure Environmental Justice: An Overview With Specific Reference to India, Philippines \& Malaysia,” [1998] 4 MLJ xxv, Abdul Aziz Bari, "Right to Life Under the Federal Constitution and Environmental Issues,” [1999] 1 MLJ lx, Gurdial Singh Nijar, "The Bakun Dam Case: A Critique” [1997] 3 MLJ ccxxix. Tan Tek Seng v Suruhanjaya Perkhidmatan Pendidikan \& Anor. [1996] 1 MLJ 261.

$20 \quad$ Hong Leong Equipment Sdn. Bhd. v Liew Chuan [1996] 1 MLJ 510.

$21 \quad$ R. Rama Chandran v The Industrial Court of Malaysia [1997] 1 MLJ 191

$22 \quad$ Lembaga Tatatertib Perkhidmatan Awam v Ultra Badi a/l K Perumal [2000] 3 MLJ 294. 
equality before the law, may be contended to support a proposition for fair treatment by the government towards disabled persons. In other words by virtue of both articles 5 and 8 there should not be any discrimination against disabled persons. ${ }^{23}$

The only case in Malaysia where the issue of the right of the disabled has been litigated in court is the case of Jakob Renner (an infant suing through his father and next friend, Gilbert Renner) and Other $v$ Scott King, Chairman of Board of Directors of the International School of Kuala Lumpur and Others. ${ }^{24}$ The case centered around the issue of the right of disabled persons to education where Jakob (the plaintiff), who is a child with mild spastic dipelgia has been prevented from continuing his education at the middle school simply because of the apparent financial expenditure that was to be incurred in making the school disabled friendly. It was contended inter alia in the above case that the act of the defendant in rejecting the application by the plaintiff to continue his schooling at the defendant school was a violation of articles 5 and 8 of the Federal Constitution (despite the fact that the plaintiff is not Malaysian, but American). The plaintiffs applied for an interlocutory injunction to restrain the defendants from preventing the first plaintiff (Jakob) from continuing his education at the defendant school. In allowing the application by the plaintiff the court decided that on a balance of justice, the apparent financial expenditure in making the defendant school disabled friendly was not legally tenable. As a matter of law and justice, financial considerations took a back seat and gave way to disabled children's basic rights to education and where the overriding educational needs of children were likely to be threatened; this would necessitate the tilting of the balance of justice in favour of providing continuance of education for the affected children.

Even though the above case is directly related to the right of a disabled child for education (which is not the focus of this paper), the important point to note here is on the non-availability of schools with barrier free designs for children with disabilities. In absence of proper infrastructure in school for the disabled, indirectly it will amount to a deprivation of their right for education. If counsel for the plaintiff wants

Another possible argument on the rights of disabled persons would rest on the issue of legitimate expectation of this minority group towards the government. 
to argue further on the right of children with disabilities, he may rely on the broad interpretation adopted by the Malaysian courts in the previous cases on the meaning of "life" as it appears in article 5, which may include the right to education too. Similarly the fundamental right of equality before the law in article 8 may be utilised to emphasise that there should not be discrimination towards the child in respect of school education.

Despite clear inclination of the Malaysian courts in approving a moderate interpretation of the word "life", one may not simply be comfortable with this trend. The creation of a legal comprehensive framework is needed because this would lead to a more serious commitment of the authorities towards upholding the rights of persons with disabilities. Accordingly proper legal and administrative mechanisms may be formulated and enforced. In Australia for instance the formulation of the Anti Discrimination Act, 1992 has promoted the enforcement of rules and regulations in preserving the rights of persons with disabilities in terms of work, accommodation, education, access to premises, clubs and sport; provision of goods, facilities, services and land; equality before the law, recognition and acceptance within the community and same fundamental rights as the rest of the community. ${ }^{25}$

At present the only regulatory structure available pertaining to rights of disabled persons in Malaysia is contained in the UBBL Amendment 1991. ${ }^{26}$ This amendment provides for specific building requirements for disabled persons. After this amendment Malaysia signed the Proclamation on Full Participation and Equality of People with Disabilities in the Asia and Pacific Region ("ESCAP”) on May 16, 1994. ${ }^{27}$

$25 \quad$ See section 3 of the Anti Discrimination Act, 1992.

26 The principal by-law is the Uniform Building By-Laws 1984 (UBBL 1984) The UBBL 1984 is the by-laws under the Street, Drainage and Building Act, 1976 and each and every state in Malaysia would have to gazette it. Until April 2006, the record of the Department of Social and Welfare, Malaysia shows that all states in Malaysia other than Sabah have gazetted the amendment to the building requirements for disabled persons.

27 Md. Rashid Ismail, Country Paper: Malaysia, a paper presented in the Expert Group Meeting and Seminar on an International Convention to Protect and Promote the Rights and Dignity of Persons with Disabilities, Bangkok, Thailand, 2-4 June 2003. 
In this proclamation the member and associate member governments of ESCAP reinforced their commitment to the full participation and equality of disabled persons. A major concern of the Asian and Pacific Decade of Disabled persons 1993-2002 is the removal of all kinds of barriers in the built environment which prevent people with disabilities from participating fully in community life. ${ }^{28}$ The significance of signing this proclamation is later reflected in the Guidelines for Planning and Total Development, 1997. ${ }^{29}$ The guidelines inter alia emphasise that planning for housing areas, public buildings, commercial buildings, transportations and recreation areas shall take into consideration the needs of disabled persons. The signing of this proclamation supposedly would lead to other pro-active steps being taken by relevant Malaysian authorities to protect the rights of disabled persons.

\section{BUILDING REQUIREMENTS FOR DISABLED PERSONS}

By-law 124A of the Building (Federal Territory of Kuala Lumpur) (Amendment) By-Laws 1992 provides that any building or any part thereof where the public or a class of the public has access with or without the payment of a fee; or any residential building other than a detached, semidetached, terrace or link, or town house, shall be provided with (i) means of access to enable disabled persons to get into, out of, and move within the building; (ii) facilities for the use of disabled person; and (iii) means of escape to enable disabled persons to get out of the building in case of emergency. It means that under this By-law all public and commercial

\footnotetext{
28 http://www.unescap.org/esid/psis/disabilitu/decade/publications/ zl15008cs/zl500802.htm

29 These guidelines are issued by the Department of Town and Country Planning, Ministry of Housing and Local Government Malaysia. The objective of the guidelines is to achieve a balance between physical development with spiritual development and good values for continuous development of the country. The guidelines serve as guidelines for physical planning; assist local authorities, state authorities, developers and other related parties involve in the planning process and development of town and country and as a reference for preparation of development plan and planning guidelines.
} 
buildings ${ }^{30}$ as well as residential units of multi-storey buildings should comply with building requirements for disabled persons. As for buildings which have been erected, or are in the course of being erected or have not been erected but plans have been submitted and approved before the commencement of this by-law, it requires that it shall be modified or altered to comply with this by-law within three years from the date of commencement of this by-law. ${ }^{31}$

In order to facilitate the implementation in all the states in Malaysia the amendment to the UBBL Amendment 1991, the technical working committee under the Local Government Department of the Ministry of Housing and Local Government has issued the Guidelines on the Minimum Building Requirements For Disabled Persons ${ }^{32}$ that shall be used to guide all parties involved in the implementation and reference material for designers (architects, engineers, planners), construction teams (developers, builders, site supervisors) and the local authorities. Besides this, there are three Malaysian Standard Codes of Practice on the accessibility and mobility for people with disabilities. These standards are:-

a. MS 1184: 1991, Code of Practice for Access for Disabled Persons to Public Buildings,

30 This may include for instance offices, post-offices, shops, department stores, supermarkets, banks, hospitals, recreation buildings, cinemas and concert halls.

$31 \quad$ By-law 124(4) of the Building (Federal Territory of Kuala Lumpur) (Amendment) By-Laws 1992.

32 These guidelines inter alia contain matrix guidelines for access to public and commercial building, design recommendation, modification of existing building and maintenance. The matrix guidelines specify the category of building and the type of facilities which are required to be provided in that specific building. For instance a hotel building with more than 100 rooms must provide ramp, toilet, mechanised vertical access, stairs, parking space, visual sign and audio signal. On the other hand the design recommended specific elements in the building to be suitable for the disabled; who are wheelchair users, persons with impaired walking, persons with upper body disability, visually-impaired/ blind persons and persons with impaired hearing. 
b. $\quad$ MS 1183:1990, Code of Practice for Means of Escape for Disabled Persons,

c. MS 1331:1993, Code of Practice for Access for Disabled Persons Outside Buildings. ${ }^{33}$

Based on the above discussions it is clear that guidance is available in promoting the accessibility of buildings to persons with disabilities. However, there are a few deficiencies as regards to the implementation of the amendment to the UBBL Amendment 1991 since not all local authorities in Malaysia have complied with it. Non-compliance of such requirements may be due to lack of qualified manpower to determine whether the building plan submitted to the local authority for approval has complied with the statutory requirements of UBBL Amendment 1991; lack of awareness and sensitivity of developers and its consultants (architects/engineers); and limited definition of persons with disabilities in UBBL Amendment 1991.

\section{(i) Lack of qualified manpower}

In Malaysia a local authority may mean a City Council, Municipal Council or District Council (as the case may be).$^{34}$ Generally all local authorities will have a department of building which will process applications for building plan approval and issuance of the certificate of fitness for occupation of buildings upon completion. ${ }^{35}$ An officer who is supposed to scrutinise the building plan should be an architect who is qualified to examine whether the plan submitted has complied with the

33 The MS 1331 is yet to be incorporated into the by-law 124A(3) of the Building (Federal Territory of Kuala Lumpur)(Amendment) By-Laws 1992.

$34 \quad$ Section 2 of the Local Government Act 1976.

35 At the time when this article is written, the Malaysian Parliament has just passed the bills of several related statutes in order to facilitate the implementation of new practice for the issuance of certificate of completion for buildings i.e. certificate of completion and compliance (CCC). This new system is going to replace the current practice of issuance of certificate of fitness for occupation. 
relevant requirements of the laws and regulations, including necessary guidelines; for instance the Guidelines as to the Minimum Building Requirements for Disabled Persons and the relevant Malaysian Standards. However not each and every local authority in Malaysia has qualified architects to discharge this duty. The architect may be available at the City Council and Municipal Council level but almost none at the District Council level. In many cases the task will be performed only by a technical assistant. On the other hand even though there is an architect, but due to numerous applications for building plan approval, he may not be able to really examine whether necessary requirements as laid down in the Guidelines on Minimum Building Requirements for Disabled Persons and relevant Malaysian Standards have been complied with or not. ${ }^{36}$

\section{(ii) Lack of awareness and sensitivity}

In situations of lack of manpower, local authorities have to place trust in the qualified person who submits a building plan. ${ }^{37}$ However due to lack of awareness among developers and its consultants (architect/ engineer), there would be great tendency when preparing a plan and design for building to neglect the aspect of accessibility of that particular building by disabled persons.

\section{(iii) Limited definition}

The Building (Federal Territory of Kuala Lumpur)(Amendment) By-Laws, 1992 defines a disabled person as a person with a physical, hearing or sight impairment which affects his mobility or his use of

36 This information is based on an interview with Ir. Fong Tian Yong of the Building Unit, Local Government Department, Ministry of Housing and Local Government, Malaysia, Level 3, Blok K, Pusat Bandar Damansara, 50728 Kuala Lumpur.

37 Under the Street, Drainage and Building Act, 1974 and the Uniform Building By-Laws, 1984, a qualified person refers to an architect, engineer or a building draughtsman registered under any written law relating to the registration thereof. 
buildings. This definition is considered as limited since it does not extend to the outside of buildings. Therefore even if the building itself is friendly to the disabled, but the access for disabled persons outside the building is not barrier free it will not facilitate disabled persons entry into the building. At present there is a Code of Practice for access for disabled persons outside buildings i.e. M.S. 1331:1993 (it has been mentioned earlier) but since it has not been integrated into the Guidelines on Buildings, it is not compulsory for such a Code of Practice to be adopted, unless and until it is specifically stated as part of conditions for building plan approval by the respective local authority. ${ }^{38}$

Due to the above drawbacks, the enforcement of laws and building by-laws are not that encouraging with the exception of new buildings at urban centres such as the Kuala Lumpur City Centre (KLCC), Kuala Lumpur International Convention Centre, Kuala Lumpur International Airport (KLIA) and office buildings at Putra Jaya.

\section{PROVISIONS FOR HOUSING FOR DISABLED PERSONS}

In Malaysia there is no directive from the government to housing developers either in the public or private sectors to build disabled friendly houses. ${ }^{39}$ Similarly there are no housing policies to encourage public or private landlords to convert existing houses to disabled friendly houses.

$38 \quad$ Recently (4 $4^{\text {th }}$ April 2006) it has been reported in all local newspapers in Malaysia that an Independent Living \& Training Centre secretary, Gurdip Kaur@ Rina, (45 years old) a disabled lady who is paralysed from the waist downwards has received a "Notice of Court Action and Warrant of Arrest” from the Klang Municipal Council (in the state of Selangor) for failure to pay parking-related compounds. She claimed that there are no parking lots for the disabled and the ticket machines are inaccessible for wheelchair-bound people.

39 There are several categories of developers involved in housing development in Malaysia. It may include private developers (privately owned companies), co-operative societies, city councils, municipal councils and state economic development corporations. Private developers concentrate more on development of medium and high cost houses. However the government has imposed a condition that at least $30 \%$ of their housing units shall be under the category of lowcost houses and to be sold at controlled prices (based on locality). 
In this part, discussions on the issue of housing with barrier free designs will focus on sub-divided buildings based on the assumption that landed houses are readily accessible by the disabled (bearing in mind with the reservations on suitability of design of floor plan and other facilities and safety aspects in houses; for instance bathroom, toilet and stair case). The issue of accessibility of housing for disabled persons in this article is considered based on two types of sub-divided buildings i.e. high-rise buildings and medium-high rise buildings.

\section{(i) High-rise buildings}

High-rise buildings refer to a more than 4 storey high sub-divided building where it is required to be provided with lift facility. However there is no requirement that the lifts shall stop at every floor/level. Similarly the suitability of that particular lift to be used by disabled persons is also uncertain since there are no standard guidelines imposed on the building plan and design. Apart from this it is unclear whether design of other parts of the building and a unit itself is friendly to the disabled. In this regard the step that has been taken by the City Hall of Kuala Lumpur in putting a requirement that all high rise and medium high rise buildings (inclusive of public housing), apartment and condominium must comply with the requirement of MS 1184:2002 that is a Code of Practice for Access for Disabled Persons to Public Buildings, ${ }^{40}$ should be followed by other local authorities. Nevertheless how far that the City Hall of Kuala Lumpur has really implemented such a requirement is still an issue that needs to be addressed. The observations in various areas of public housing in Kuala Lumpur have shown that the accessibility to the built environment is still at stake. For instance link from the drop-off area/ parking to the building/lift area obstructed by drain, steps and pedestrian rail, link to the neighbourhood amenities such as playgrounds, shops, laundry etc. obstructed by drains and steps, access from the main road to the building obstructed by steps and pedestrian rails, entrance to the lift obstructed by curb, the size of lift too small for wheel chair users, the lift buttons are too high and without Braille plates, no handrail provided in

40 By-law 3(3)(a) of the Building (Federal Territory of Kuala Lumpur)(Amendment) By-Laws, 1992. 
the lift, the opening to the unit and spaces in the unit is too tight for wheelchair users, entrance to the unit and washroom obstructed by the steps and drops, the door and size of the washroom is too tight and not provided with the grab bar. ${ }^{41}$

On the other hand as far as multi-storey low-cost houses in Malaysia are concerned, the plan and design have to be consistent with the requirements of Malaysian Standard of CIS 2; 1998. ${ }^{42}$ However none of the contents of the CIS 2 (as well as CIS 1) provide any requirement for barrier free design housing. The requirements laid down in these 2 CIS's actually are a simplification of the requirements for residential buildings as already stated in the Uniform Building By-Laws, 1984 but prior to its amendment in 1991. It makes no mention at all about the design requirement for disabled persons. Similarly the Guidelines and Matrix for Planning for multi-storey building for medium cost houses ${ }^{43}$ also does not specifically provide for barrier free design.

\section{(ii) Medium-high rise buildings}

Medium-high rise buildings are a 4 storey or less sub-divided building and it is not required to be provided with a lift. It means that a building is accessible through staircase only. Clearly this type of building is not accessible at all by those who are physically disabled.

In all of the above types of multi-storey sub-divided buildings (either high-rise or medium high-rise), the ground floor shall be reserved

$41 \quad$ Abdul Razak Sapian and Azlinor Sufian, 'Public Housing and Facilities for Disabled Persons: A Focus on the Provision of Public Housing by the City Hall of Kuala Lumpur' a paper presented at the International Conference on Sustainable Housing, organised by School of Housing, Building and Planning, University of Science Malaysia, $18^{\text {th }}-19^{\text {th }}$ September 2006. There is another Malaysian Standard known as CIS 1:1998 that is applicable for the single and double-storey low-cost houses. The CIS 1 and 2 prepared by the Construction Industry Development Board as guidelines for a proper and comprehensive development of low-cost houses with the aim to improve the quality of life and environment. Planning (3/2003) of the Ministry of Housing and Local Government. 
for social activities of the community and allocated for a few shops and laundry services. ${ }^{44}$ Thus in general multi-storey buildings in Malaysia are not friendly to the disabled. At present it is a practice that a disabled person who purchases low-cost house shall be given priority to acquire the lowest floor. But of course there will be only limited number of units available. Therefore there is a need for proper laws and legislation as well as guidelines for public housing to be of a barrier free design which should be incorporated both in the CIS 1 and 2 .

\section{PRACTICES IN SINGAPORE}

In Singapore, as early as 1978, all of Singapore's New Town centres and the ground floors of housing blocks built by the Housing and Development Board (HDB). ${ }^{45}$ HDB has taken different approaches to provide barrier free environment in public housing i.e for the new building and the existing building. The barrier-free design provisions of HDB flats are divided into three levels; i.e. at levels of the neighbourhood, precinct and apartment block. At the neighbourhood level, a network of barrier-free and vehicular-free walkways is provided to connect each precinct to the amenities within its neighbourhood. At the precinct level, drop-off porches with barrier-free access from the driveways to the walkways that connect the multi-storey car parks with the blocks. Other barrier-free access features within the precinct include the provision of paved surface car parking lots specifically for the disabled and ramps leading to the block. At the block level, lift stops have been provided at every floor. In addition, lift cars are provided with features such as handrails bars, lower lift call buttons, and doors wide enough for wheel chairs. Besides that Voice Synthesizer and Braille plates for the visually disabled have been incorporated in all lifts. Multi-storey car parks are

This is the Matrix for Planning of Multi-Storey Housing Unit, Department of Town and Country Planning (2/99) of the Ministry of Housing and Local Government.

$45 \quad$ Harrison, James D.1991. "Recent advances in accessibility legislation and incentives in Singapore.” Internet publication URL: www.independentliving.org/cib/cibbudapest12.html 
also designed with lift shafts to allow for the provision of lifts when the need arise. ${ }^{46}$

The HDB also provides a Specially Design Flat for the Elderly. The studio apartments designed specially for the elderly come with preinstalled fixtures and fittings with special safety and elderly friendly features that meet the more specific needs of the elderly. To facilitate mobility for the more frail elderly, there are support hand-bars in the bathrooms, wider main doors that allow for wheelchair access and completely level floors with no curbs. ${ }^{47}$

On the other hand for existing building there are 3 programmes runs by the HDB to improve the existing building and provide them with disabled and elderly-friendly features. The 3 programmes are; Main Upgrading Programmes, Project to Improve the Living Conditions of the Elderly and Lift Upgrading Programme. In the Main Upgrading Programme the internal of the flats, the common areas in the blocks and the external built environment are made more elderly friendly and accessible. It includes the provision of pedestal pans and grab bars in the toilets, and brighter light fittings for better visibility. Barrier-free accessibility to all facilities within the housing precinct is ensured with the provision of ramps, railings, drop-off porches and covered walkways. As for the Project to Improve the Living Conditions of the Elderly, the public areas are modified to make them more accessible. Lift landings are added on every floor and some units are removed to provide spaces for social interaction. The doubled-loaded corridors are brightened up with artificial lightings and handrails for elderly who have difficulty in walking. Within the flats, doorways are widened and curbs are removed so that a wheelchair can be used easily. In the kitchen, lowered worktops, power points at reachable heights and lever-type taps in the basins and sinks are provided. In the toilets, pedestal type water closets replace the original squat pan and grab bars are available. Pull-chords linked to an alert alarm system are provided at the toilet and living area. In the Lift Upgrading Programme, it improves the flat's accessibility and personal convenience. It compliments the Main Upgrading Programme where it provides that lifts will stop at every level. ${ }^{48}$

\begin{tabular}{ll}
\hline 46 & www.bca.gov.sg/BarrierFree/others/HDB.pdf \\
47 & Ibid. \\
48 & Ibid.
\end{tabular}


Another interesting point is on tax incentives provided by the Singapore government through a special scheme since 1989. The scheme was to encourage employers to modify their existing premises to allow access for physically disabled staff, wherein the costs of such improvements can be offset against tax, provided the work complies with the Code on Accessibility. Apart from that the Singapore Council of Social Service together with the volunteer members of the Singapore Institute of Architects offer advice to interested employers on the ways in which they might enhance their workplaces. ${ }^{49}$

\section{SOME POINTS FOR IMPROVEMENT}

All local authorities in Malaysia may have to consider including requirements for compliance with the UBBL Amendment 1991, as one of the compulsory requirements for the approval of any plan for public and commercial building and residential units. There is a need for increase of manpower in the local authorities so that local authorities will be able to overcome the problem of lack of personnel to monitor the implementation of building requirements for the disabled. ${ }^{50}$ Thus it will be possible to conduct the tests on accessibility of buildings prior to the handing over of vacant possession of the building. A resource person who is a disabled person may be invited by the respective local authority to test whether certain designs are workable or practical. For instance whether lift buttons can be accessed by a wheel chair user or whether toilets are spacious enough for wheel chair users to enter into.

The design guidelines for public and commercial buildings that are currently adopted in Malaysia may be extended to public housing but with necessary modifications. Thus if the UBBL Amendment 1991 is to be integrated into the CIS 1 (as well as CIS 2), it shall take into consideration the existing requirement of minimum size of floor area for

\footnotetext{
$49 \quad$ Ibid.

50 In United Nations, 1995, Promotion of Non-Handicapping Physical Environments for Disabled Persons, United Nations, New York it has been commented that in Malaysia very little monitoring takes place to evaluate how far the Guidelines on Building Requirement for Disabled Persons are complied with.
} 
a low-cost unit that is only 63 sq. meters which may not convenient for wheel chair users.

Besides that the Department of National Housing ${ }^{51}$ which is responsible for the planning and implementation of low-cost unit for the lower income group in Malaysia may have to work on a flexible housing policy to cater to the needs of disabled persons.

Meanwhile housing developers from the public sector i.e. local authorities and the State Economic Development Corporations may take initiative to develop certain units of houses in their project that suitable for persons with disabilities. They have to be more responsible since the disabled persons from the lower income group may not afford to purchase houses developed by the private sector. In this respect there is a need to have a proper coordination between local authorities and government departments. For instance local authorities or the State Economic Development Corporation may utilise the records/statistics from the Department of Social Welfare as a basis for planning the development of low-cost units for disabled persons within a specific locality.

Generally the real estate development is driven by consideration of profit maximisation and work within minimum cost. However it is a responsibility of the Ministry of Housing and Local Government to take positive steps towards creating awareness among designers, builders and developers (as well as other stakeholders in the construction industry; for instance engineers and manufacturers of building materials) as to the need of suitable housing design and furnishings for disabled persons. Consequently, the ministry may have to draw up guidelines for structural modification in housing projects. An incentive should be given to developers who construct barrier free houses. The creation of special awards for developers that construct barrier-free buildings as available in other countries for instance Australia, Singapore and Ireland may be adopted by the Malaysian Construction Industry Development Board. In the United Kingdom special grants/loans are available for any disabled person who needs to modify his/her house.

$51 \quad$ Established by the Ministry of Housing and Local Government. For further information about the department refer to http:// www.kpkt.gov.my/jpn/garispanduan.htm. 


\section{CONCLUSION}

There is a need for legislative and policy response towards the needs of disabled people for accessible built environment in terms of buildings and housing in Malaysia. Even though there are guidelines to developers to provide barrier free public buildings, there is lack of monitoring and enforcement to evaluate the extent of which those guidelines have been adhered to. On the other hand as far as housing is concerned, disabled persons are at the mercy of developers to develop barrier free housing (especially the multi-storey housing units) since there is no law or policy to enforce or encourage developers to construct the same. It is hoped that Malaysian policy makers, urban planners, architects, designers and local authorities will take into account the practices in other jurisdictions as references for the construction of disabled-friendly buildings and housing. It is mentioned clearly in the Ninth Malaysian Plan that continuos efforts will be undertaken to assure that Malaysians of all income levels will have access to adequate, quality and affordable houses, particularly those from the low income group. This government agenda is supposed to take into account the meaning of 'adequate' and 'quality' houses to include the houses that would cater the needs of this minority group. 